\title{
Hydrodynamics Modeling of Khung Krabaen Lagoon, Chanthaburi Province, Thailand
}

\author{
Pokavanich Tanuspong ${ }^{1, *}$, Buranapratheprat Anukul ${ }^{2}$, and Aryuthaka Chittima $^{1}$ \\ ${ }^{1}$ Department of Marine Science, Faculty of Fisheries, Kasetsart University, Bangkok, Thailand \\ ${ }^{2} 2$ Department of Aquatic Science, Faculty of Science, Burapha University, Chon Buri, Thailand
}

\begin{abstract}
Khung Krabaen Lagoon (KKBL) is a small low-inflow water body. There are vast areas of tidal flat occupied nearly $60 \%$ of the lagoon that host some of the most productive seagrass habitats in the region. The lagoon is surrounded by mangrove forest and intensive shrimp farms behind it. The KKBL was used as an intake and recipient water for the farms. However due some shrimp disease epidemics and possibly deteriorated water quality, the farms are now taking the intake water from the outer sea through very expensive (to construct and to maintain) irrigation system. Objective of this study is to investigate the KKBL's hydrodynamics using a numerical simulation model validated with measured data. The simulation model was setup two-dimensionally based on the Delft3D model. Results suggested that water currents inside, at the mouth and at the outer sea of the lagoon are mainly governed by tide and wind. Offshore of the lagoon, there are strong tidal currents flowing along northwest and southeast direction. The tidal currents flow into the lagoon through its mouth before dispersion rapidly inside the lagoon. Mean circulation largely varied seasonally and had direct correlations outer sea seasonal mean currents and the monsoons.
\end{abstract}

\section{Introduction}

Khung Krabaen Lagoon (KKBL), also known as Kung Krabaen Bay, is a small low-inflow water body situated at the eastern part of Thailand. According to the Kung Krabaen Bay Royal Development Study Center. The KKBL was formed naturally by mountain erosion and coastal currents generated Tombolo and gradually drop of the sea level. This form of water body origin is typical for a lagoon. Therefore the Kung Krabaen is called a lagoon rather than a bay in this study. Coverage area of the KKBL about $6.7 \mathrm{~km} 2$ (Fig. 1). Shape of the lagoon resembles shape of "Krabaen" meaning sting ray in Thai. The lagoon has narrow mouth and has its body oriented along northwest and southeast axis. Dimension of the lagoon along the axis is approximately $3.6 \times 2.5 \mathrm{~km}$. It has approximately $11 \mathrm{~km}$ long coastline which is surrounded by mangrove forest and vast area of tidal flats. The tidal flat occupied nearly $60 \%$ of the lagoon that host some of the most productive seagrass habitats in the region. The KKBL is a shallow water body and has no major freshwater source discharged into it.

The KKBL was used as an intake and recipient water for some intensive shrimp aquaculture complex in the country since 1986 (Sangrungruang et al., [1]). The complex is located right behind the mangrove forest. However due some shrimp disease epidemics and possibly deteriorated water quality, the complex is now taking the intake water from the outer sea through very expensive (to construct and to maintain) irrigation system. It has been reported also that there has been a decline of coastal fish stocks at the KKBL. Sangrungruang et al. [1] also reported that activities of the shrimp farming deteriorate sediment quality and adversely affected the lagoon's sea-shore communities. It is clear that human developments at the KKBL is not sustainable and to meet the challenges, not only proper planning, design, implementation of infrastructure, but also clear policy and strategy direction of the infrastructure are required through better understanding of the water system. Objectives of this study is to update and provide some fundamental understandings of the hydrodynamics of the KKBL in which described with insufficient details by Sasaki and Inoue [2].

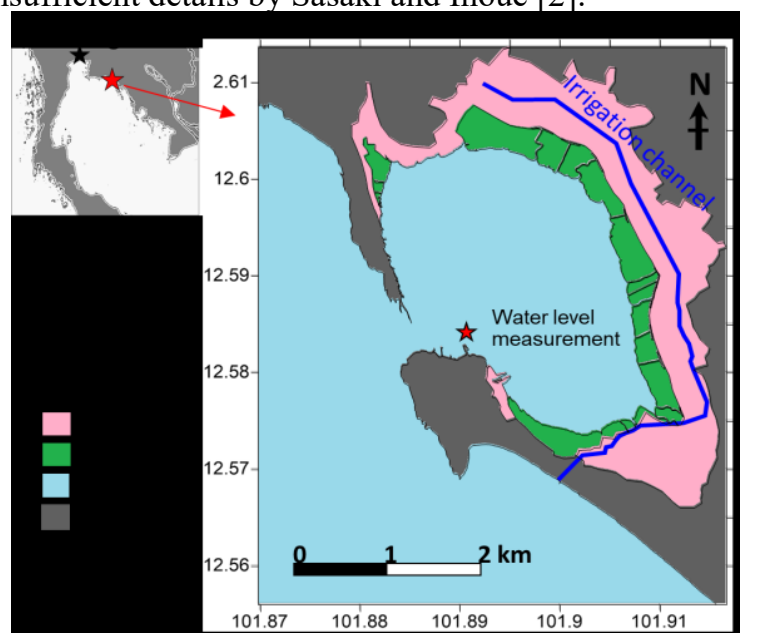

Fig. 1. Location maps of study site and measurement.

\footnotetext{
* Corresponding author: ffistop@ku.ac.th
} 


\section{Field Observation}

There are very limited field observations for the physical oceanographic characteristics of the KKBL. In this study, two preliminary hydrographic survey were carried out between 24th April to 13th May 2017 to obtain spatial variation of water depth and temporal variation of water level. The water depth survey utilized an echosounder (HDS-9, LOWRANCE-USA) for the day and night survey to cover the whole area of the lagoon. Fig. 2 shows a photo of the model, model setting up on a boat and measurement track. The water level survey measured water depth temporal variation for 15-days using an automatic pressure logging sensor (HOBO Water Level Logger, ONSET-USA) at 30 minute interval. The sensor was placed in a PVC tube tighten to a stable concrete column at a fish cage located at $12^{\circ}$ $34.96{ }^{\prime} \mathrm{N}$ and $101^{\circ} 53.42^{\prime} \mathrm{E}$. Fig. 3 shows details of the pressure logger deployment. The recorded pressure data was convert to water depth by assuming constant water density and constant atmospheric pressure. The water depth were subtracted by its 15 -day averaged value to produce the water level (from Mean-Sea-Level, MSL). Measured data from the depth survey was corrected to the MSL depth using measured water level in this study.
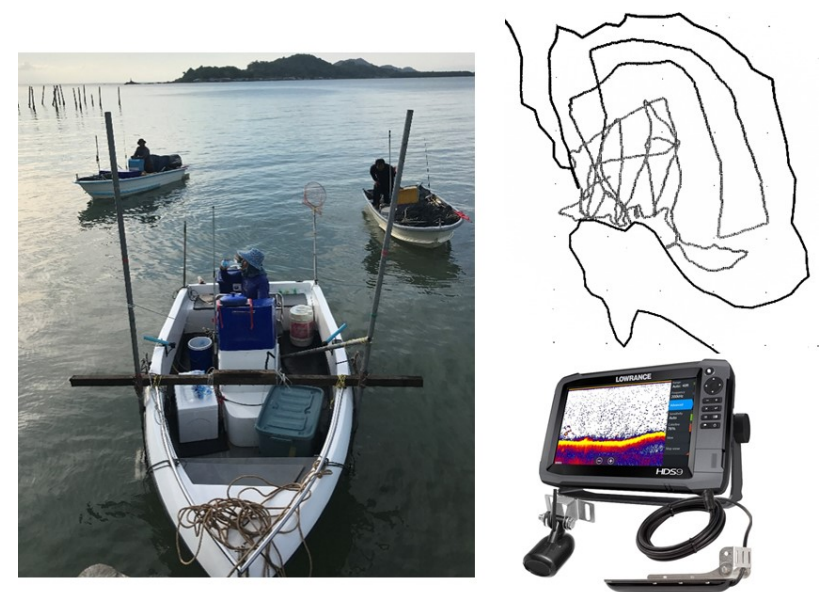

Fig. 2. LOWRANCE HDS-9 echo sounder, its field setup and measuring route of the water depth survey conducted on 24th April 2017

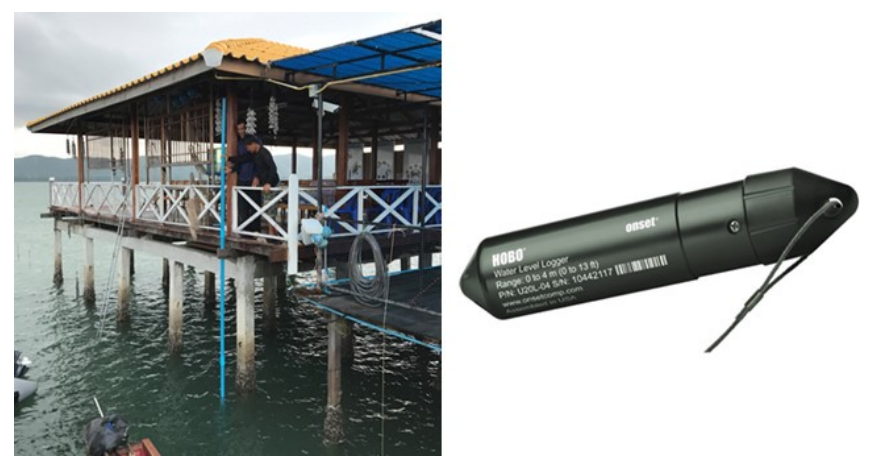

Fig. 3. HOBO water level logger and its deployment methodology for the water level variation survey between 24th April and 13th May 2017

\section{Setting Up Numerical Model}

In this study, two-dimensional (depth averaged) hydrodynamic modeling of the KKBL applied a wellestablished program named Delft3D-FLOW (Deltares, [3]). Two hydrodynamic models were set up, i.e., a coarse resolution model that covers whole area of the Gulf of Thailand (GOT) called GOT Model and a fine resolution model that covers whole coastal waters of the Chanthaburi Province including the KKBL area called Chathaburi model. Fig. 4 show the overall coverage area and calculation mesh of both models. Fig. 5 shows interpolated depth data used for the coarse model and at the KKBL. Bathymetric data applied here were derived from a newly measured water depth conducted in this study, digitized navigational charts from the Hydrographic Department, Royal Thai Navy adjusted to the mean sea level and from the ETOPO1 1/60 data (http://www.ngdc.noaa.gov/mgg/global/global.html).

The GOT model were forced at offshore boundaries by a set of tidal constituents derived from time-series data from TPXO6.2: Global Inverse Tide Model (Egbert and Erofeeva, [4]). Time-series of simulated water level at five locations situated along the offshore boundaries of the Chanthaburi Model were forced that derived from the GOT model. The simulation for year 2011 applied spatial and temporal varying wind data at 6 hourly interval with 2.5 degree resolution from NCEP/NCAR Reanalysis 1 (Kalnayet al., [5]). The validating simulation for year 2017, applied 3 hourly measured wind data from Chathaburi Meteorological Station $\left(12^{\circ}\right.$ $\left.37.00 \mathrm{~N}, 102^{\circ} 06.80 \mathrm{E}\right)$ from Thailand Meteorological Department. Bed roughness coefficient was uniformly applied. General setup of the GOT and Chanthaburi model are given in Table 1.

Table 1. General setup of the hydrodynamic model for the KKBL

\begin{tabular}{|c|c|}
\hline Item & GOT \& Chanthaburi \\
\hline $\begin{array}{c}\text { Simulation } \\
\text { period }\end{array}$ & 1 January 2011-31 December 2011 \\
\hline $\begin{array}{c}\text { Validation } \\
\text { period }\end{array}$ & 1 January 2017-31 May 2017 \\
\hline Mesh & Curvilinear grid in spherical coordinate \\
\hline Time step & 3 minutes \& 1 minute \\
\hline Initial condition & Uniform rest water \\
\hline $\begin{array}{c}\text { Bottom } \\
\text { roughness }\end{array}$ & Chezy 100 \\
\hline $\begin{array}{c}\text { Horizontal eddy } \\
\text { viscosity }\end{array}$ & $10 \mathrm{~m} 2 / \mathrm{s} \& 1 \mathrm{~m} 2 / \mathrm{s}$ \\
\hline
\end{tabular}




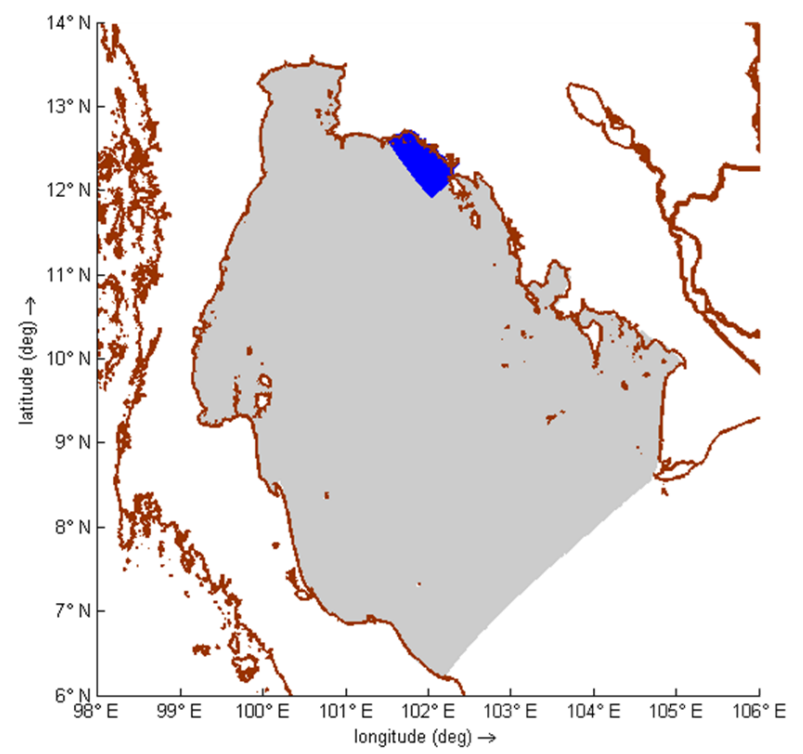

Fig. 4. Calculation mesh of the GoT model (grey) and Chathanburi model (blue)
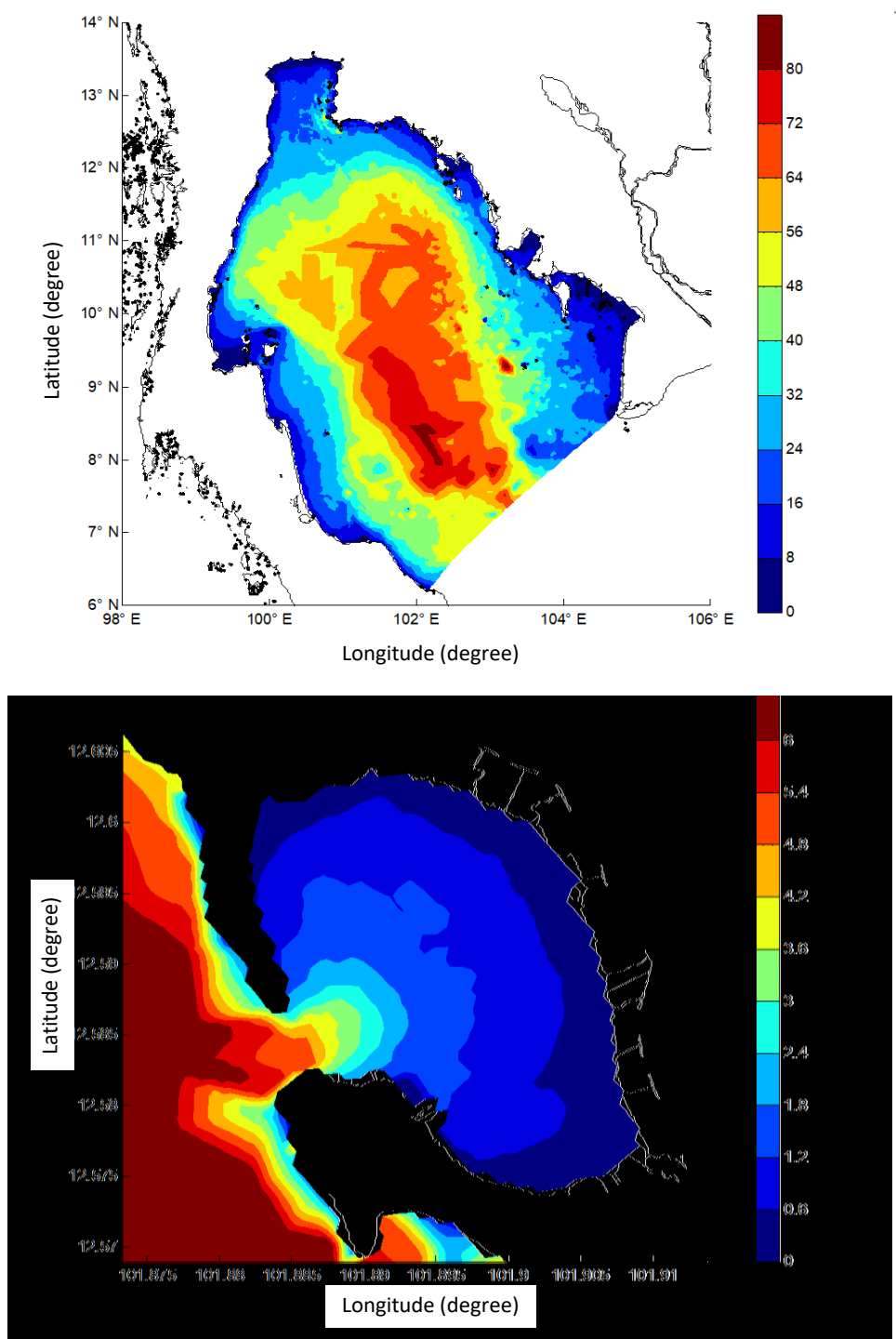

Fig. 5. Interpolated water depth data for the GoT and the KKBL area. Unit in meter.

\section{Results and Discussion}

\subsection{Model validation}

Hydrodynamic models were validated with water level data measured at a location inside the KKBL shown in Fig. 6. Results suggested that the Chathaburi Model can reproduce tidal water level variations very well in terms of amplitude and phase. This suggests that the model can reproduce the barothopic tidal currents and wind-driven current with acceptable accuracy.

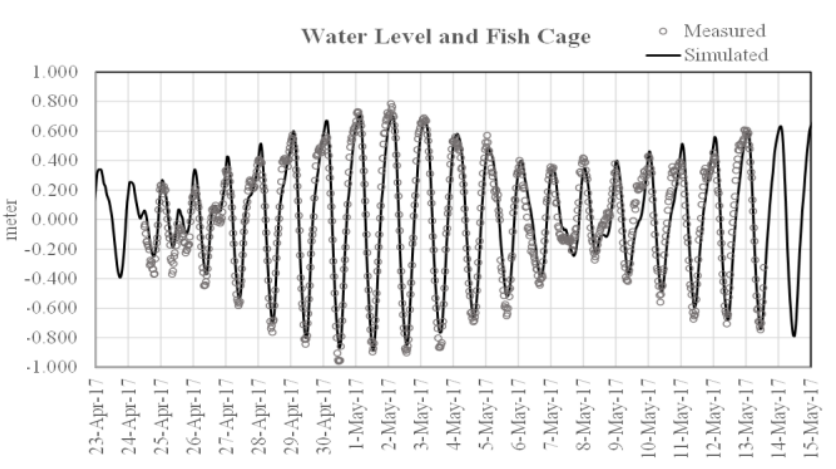

Fig. 6 Comparison between measured and simulated water level variation inside the KKBL for 15 days

\subsection{Hydrodynamic characteristics of the KKBL}

Results of this study, during the water level measurement period, tidal ranges during spring and neap tide are $1.6 \mathrm{~m}$ and $0.6 \mathrm{~m}$, respectively. Detailed calculation in this study suggested that the lagoon has averaged depth is $0.77 \mathrm{~m}$-MSL. Horizontal area of the lagoon is approximately $6.69 \mathrm{~km} 2$ and calculated volume of the lagoon at MSL is $5.14 \mathrm{~km} 3$. Due to the fact that the KKBL is very shallow compared to its tidal ranges. Tidal current plays dominant role in pushing and drawing water and material in the water in and out of the KKBL. Fig. 7 and Fig. 8 show current characteristics at different tidal phases at spring and neap tide, respectively. Note that there are vast areas dry up at low and ebb tide inside the bay (areas in brown color).

Tide at the KKBL is mainly diurnal that raise and fall generally once a day. Tidal currents at the mouth of the lagoon can reach the speed of $0.42 \mathrm{~m} / \mathrm{s}$ during the spring tide and are around $0.15 \mathrm{~m} / \mathrm{s}$ during neap tide. The currents gradually reduce their speed once enter the lagoon. At the middle of the lagoon, the current's speeds are $0.18 \mathrm{~m} / \mathrm{s}$ during spring tide and $0.08 \mathrm{~m} / \mathrm{s}$ during neap tide. General directions of the tidal current are northwest and southeast at the outer sea, northeast and southwest at the mouth and toward and from the coastline at the region inside the lagoon. 


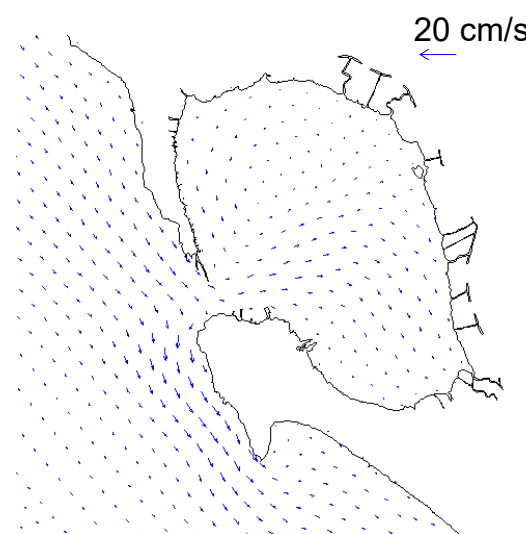

(a) High tide - 5:00

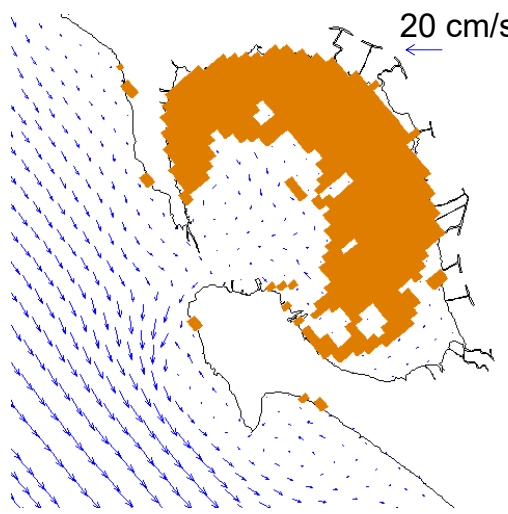

(c) Low tide - 15:00

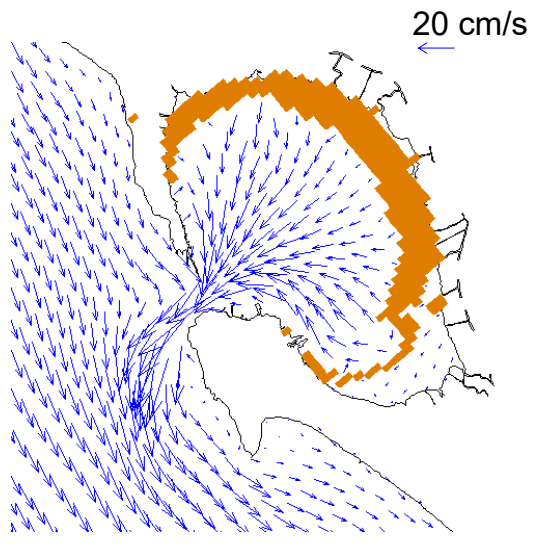

(b) Ebb tide - 11:00

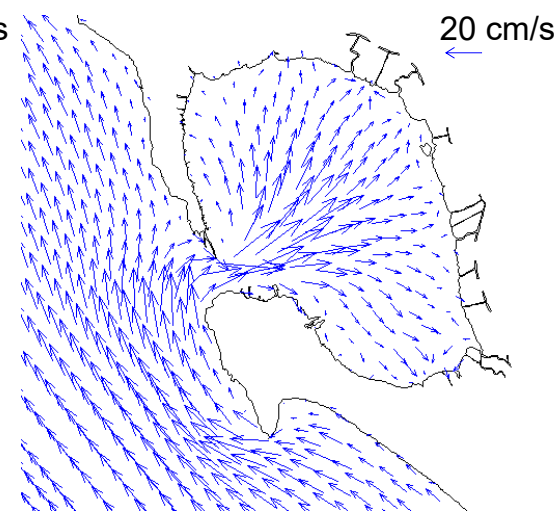

(d) Flood tide - 21:00

Fig. 7. Flow velocity patterns (blue arrows) and dry-up tidal flats (brown areas) at different tidal phase during spring tide on 13th January 2017

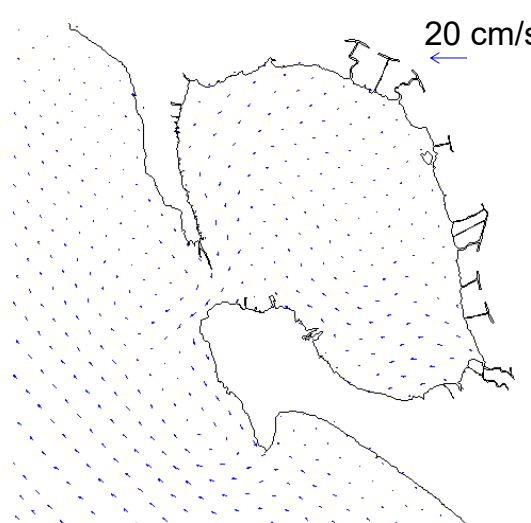

(a) High tide - 3:00

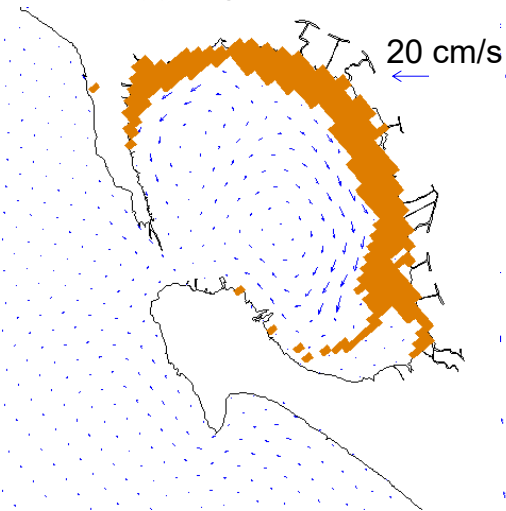

(c) Low tide - 15:00

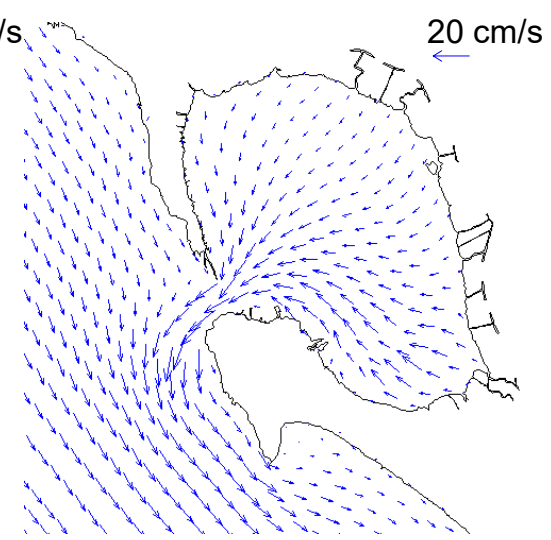

(b) Ebb tide - 8:00

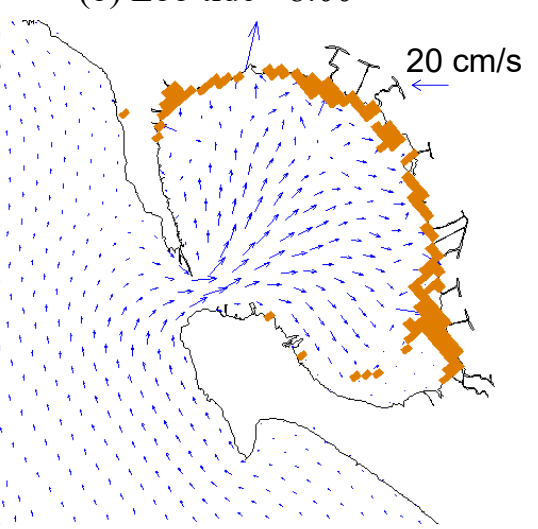

(d) Flood tide - 20:00

Fig. 8. Flow velocity patterns (blue arrows) and dry-up tidal flats (brown areas) at different tidal phase during neap tide on 20th Januarv 2017 


\subsection{Mean water circulation affected by topography and monsoonal wind}

Apart of investigating the short-term hydrodynamic features of the KKBL by tide, this study also studied long-term hydrodynamic characters of the lagoon affected by monsoonal wind by means of the monthlymean flow velocity. Fig. 9 shows monthly residual flow velocity fields or monthly-averaged velocity fields of the lagoon at different monsoonal time in Thailand. According to a report prepared by Thailand Meteorological Department (https://www.tmd.go.th), climate in Thailand is dominated by Northeast (NE) Monsoon between middle of October to middle of February and by Southwest (SW) Monsoon between middle of May to middle of October. From April to middle of May are considered as a transition period between the two monsoons.

As can be seen in Fig. 9, there are distinct differences features of the mean flow velocity fields (mean circulation) at different monsoonal period. During the NE monsoon, offshore mean current flow toward northwest direction and generate clockwise gyre with diameter of around $1 \mathrm{~km}$ located in front of the mouth of the lagoon. There is a strong inflow current straight from the mouth flowed through the middle of the lagoon. The current deviated to right and left side once reaching the coastline and splitted the lagoon into two circulation cells, i.e. counterclockwise in the cell at the northwest and clockwise in the cell at the southeast. During the transition between NE monsoon and SW monsoon, the feature of the offshore mean current drastically changes. The strong northwest flowing current and the clockwise gyre at the front of the lagoon's mouth relax. The strong inflow current from the mouth to the inner part of the bay disappeared and a counterclockwise gyre with the same scale of the mouth was generated. The mean current in the lagoon is sluggish and has not visible trend. During the SW monsoon, offshore mean currents rapidly flow toward the southeast direction. The gyres at the mouth disappeared. There is a strong out-going current flowing straight toward the mouth of the lagoon but deviate to northwest and southeast direction before leaving the lagoon. The deviated currents form two gyres inside the lagoon, i.e., the clockwise and counterclockwise gyres at the northwestern and southeastern part of the lagoon.

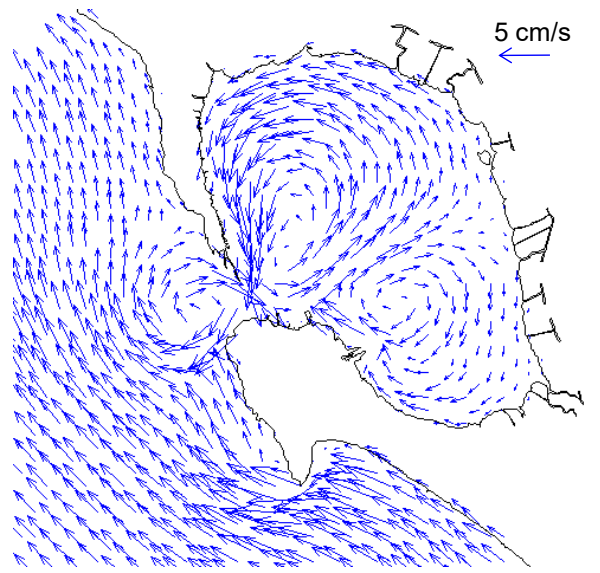

(a) January (NE monsoon)

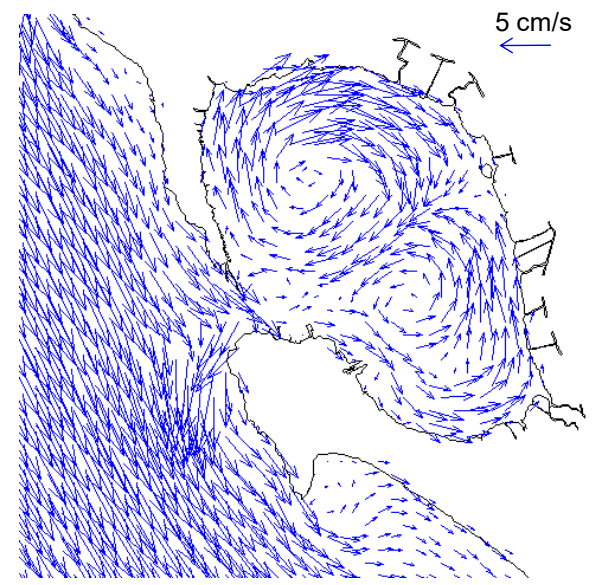

(c) August (SW monsoon)

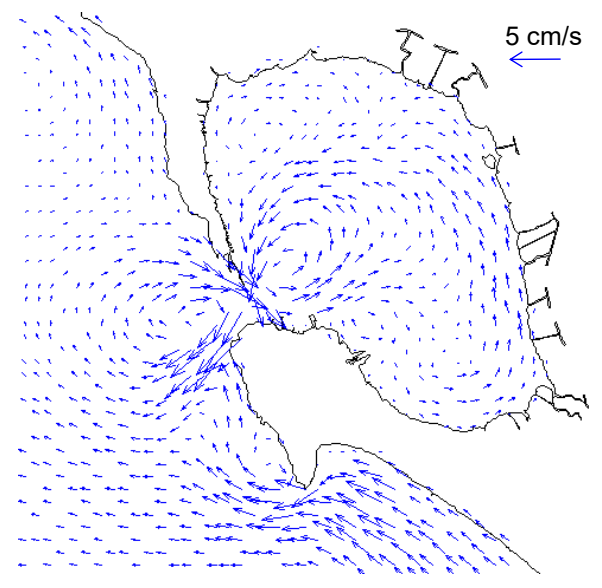

(b) April (transition)

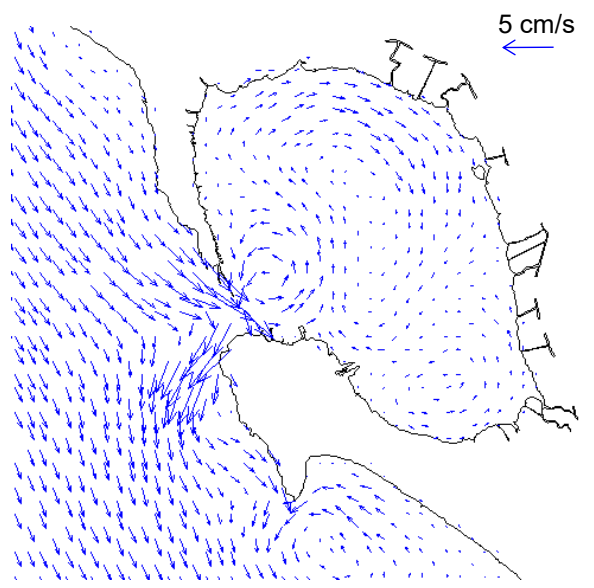

(d) October (transition)

Fig. 9. Monthly residual flow velocity (averaged flow velocity) fields at different months in year 2011 


\section{Concluding Remarks}

Present study reports about a hydrodynamic characteristics of a small shallow seawater lagoon with low-inflow. When compare the lagoon averaged depth and its tidal features, we speculated that the lagoon water column should be well-mixed especially during the spring tide. Two-dimensional hydrodynamics model of the KKBL was developed and the model perform very well when compared with the measured water level data at a station inside the lagoon. Results of the model suggested that tide and wind dominate overall hydrodynamics of the lagoon. While tides dictate the diurnal fluctuating current, the monsoon winds dominate overall water and material circulation patterns at the outer sea and inside the lagoon. Findings of this study also imply that there are important seasonal variations in residence time of water inside the lagoon and carrying capacities of the lagoon. To legitimately confirm this, future study is needed for the model validation against the flow velocity and other physical parameters. Threedimensional model to investigate of effects of water temperature and seawater salinity variations to the hydrodynamics of the lagoon is needed. Details circulation patterns, the characteristics of mixing and transport pathway should be further investigated in the near future. They will be useful for the water resource management of the lagoon.

\section{Acknowledgement}

The authors would like to convey their sincerely thanks to the Southeast Asian Fisheries Development Center (SEAFDEC) for providing the echo-sounder for the bathymetry survey especially to Mr.Isara Chanrachkij and Dr.Nopporn Manajit for their full supports, to the Kung Krabaen Bay Royal Development Study Center for permission to install instrument and all assistance for the water level measurement and to the Thailand Meteorological Department for providing the wind data. This study is a self-funded research project under Kasetsart University Research and Development Institute.

\section{References}

[1] C. Sangrungruang, W. Sakares, M. Anongponyoskun, B. Damrak, KKBRDSC, (1999)

[2] T. Sasaki, H. Inoue, In: Mangrove Estuarine Ecology in Thailand, Thai-Japanese Cooperative Research Project on Mangrove Productivity and Development, (1985)

[3] Deltares, Delft3D-FLOW User Manual, Hydro Morphodynamics, (2011)

[4] G.D., Egbert, S.Y. Erofeeva, J. of Atm. and Ocean. Tech. 19(2) (2002).

[5] E. Kalnay, and Coauthors, Bul. of Amer. Met. Soc. 77, (1996). 